\title{
Developing College Students' Soft Skills through Generative Learning Model
}

\author{
${ }^{a}$ Yetti Ariani \\ aPadang State Universiti, Kota Padang, Indonesia \\ Corresponding e-mail: arianiyetti@gmail.com
}

\begin{abstract}
Generative learning method is based on constructivism theory with assumption that students develop mathematics knowledge actively. The analysis of this experiment research shows that the implementation of generative learning model in Mathematics Instruction course in the Faculty of Education UNP improve students' soft skills better than the conventional learning model. The skills that were developed are modeling skills, logical thinking skills and problem solving skills. The highest score of mathematical concept understanding test in experiment class is 92.86 and the lowest is 46.43 while in control class, the score is 85.71 and 35.71 respectively. The mean of experiment class is 73.81 and 63.10 for control class.
\end{abstract}

Keywords: Soft Skills, Generative Learning Model, Mathematics Instruction in Elementary School

Topic Area: Collaborative and Problem-Based Learning

\section{PRELIMINARY}

Creating an inspiring, creative, and enthusiastic classroom atmosphere is one of the duties and responsibilities of a lecturer. That way, the learning time becomes a time that students are looking forward to. However, this task is not easy. the era of information and technology has begun to explore all aspects of life. Similarly, life competition becomes increasingly tight. How a lecturer becomes a creative figure and example for every score and achievement of student competence is a challenge. To improve the quality of student learning, it takes a creative process in lectures. The point is the important efforts undertaken to utilize the cognitive and affective potential of students optimally, so that new ideas and intelligent more accommodated. The creative process also means how to make every student have a multiperspective and a broad perspective on a fact. The creative process also means that every student is able to observe the details that are the reference in the opinion and solve the problems, both for himself and the community in society.

$$
\text { Department of Primary Teacher }
$$
Education (Faculty of Education, Padang State University) is one of the university of primary school teachers, the most preferred course of study by prospective students, based on the number of secondary school students who enroll in the SBMPTN exam in the last five years. In general, prospective PGSD students in Indonesian University always come from different majors, such as department of culinary, accounting, tourism, business, management, machine, building, electricity, and others. Similarly, it can also be from high school, MAN, SAA majoring in Science, IPS and Language, and so forth.

Realizing the importance of mathematics, pre-service teachers in primary school are expected to master mathematics material. The conceptual understanding is very important in learning mathematics because the concepts in mathematics are interrelated. In other words, to understand a concept requires a 
good understanding of the concept of its preconditions. If students are not able to understand the concept of mathematics, then other mathematical learning objectives such as using reasoning, communicating ideas, solving mathematical problems, and appreciating the usefulness of mathematics will not be achieved. It is caused by understanding of mathematical concepts is a foundation that strongly supports the achievement of other mathematics learning objectives. To overcome this problem, lecturers can apply Generative Learning Model (GLM). This is based on constructivism with the assumption that students are actively building mathematical knowledge. According to Osborne and Wittrock (1985):

Generative learning is a learning model that emphasizes on actively integrating new knowledge using the knowledge already possessed by previous students. The new knowledge will be stored in answering related issues or symptoms. If the knowledge succeeds in answering the problems encountered, then the new knowledge will be stored in long-term memory.

According to Osborne and Wittrock (1985), LGM consists of five stages: the orientation stage, the idea-disclosure stage, the challenge and restructuring, the implementation stage, and the look-back stage. At the orientation stage students are motivated to learn the material taught. Then at the stage of the disclosure of ideas, students are given the opportunity to express their ideas about the concepts being studied. Then at the stage of challenge and restructuring, the lecturer raises cognitive conflict by preparing the conditions in which the student is asked to compare his opinion with the opinion of his friend, as well as strive to reveal the truth/ excellence of his opinion. Furthermore, at the application stage students apply their initial concepts plus new concepts they get on mathematical problems in the form of exercise questions. Lastly at the re-viewing stage students are given the opportunity to evaluate the weaknesses of their concepts, then choose the most effective way/concept to solve the problem.

The disclosure stage of the idea is thought to increase the indicator of concept understanding 're-states a concept' because in this stage students are given the chance to express their ideas within the group about the concepts being studied. Then, when they have disagreements with their friends, there will be dissatisfaction which will increase their concern for their own ideas so that they will discuss the concept again and explain it.

The challenge and restructuring stage is expected to improve the conceptual understanding indicator: 're-stating a concept; using, utilizing, and selecting a particular procedure or operation; and applying the concept or problem solving algorithm' as in this stage students are given challenging problems to apply the concept that they have acquired by the aim of structuring their understanding of new concepts more steadily.

The application stage is thought to increase the indicator of concept understanding: 'classifying objects according to certain concepts (conforming to the concept); presenting concepts in various forms of mathematical representation; developing sufficient conditions or sufficient conditions for a concept; using, utilizing, and selecting specific procedures or operations; and applying the concept or problem-solving algorithm' because in this stage students are 
given the opportunity to solve more complex and varied problems using the correct concepts they have built.

The learning process with GLM requires lecturers to dig the ideas from students by asking what concepts can be related to the material that will be discussed. In putting forward the idea, the student will connect learning experience which he/she has previously experienced (initial concept) to the idea in the topic he/she will be studying. After that, the lecturer directs the students to construct the concept through questions that are digging information by linking the initial information with the new information.

Generative Learning Model provides an opportunity for students to actively construct their own knowledge and care about the initial conception (especially misconception students). By applying the Generative Learning Model, it is expected that the 'Mathematics Learning in SD' which is followed by the students is better because in the Generative Learning Model, there are activities of constructing, discussing, questioning between the students and lecturers, and the activities of trying out the concept that students get into mathematical problems. In addition, Generative Learning Model can encourage the participation of students to express their opinions on a problem that is in the stage of idea disclosure.

\section{Literature Review}

\section{A. The Understanding of Mathematics Concept}

Pemahaman is defined from the word understanding. The degree of understanding is determined by the degree of relevance of an idea, procedure or mathematical fact understood comprehensively if it forms a network with high relevance. Then, concept is defined as an abstract idea that can be used to classify a set of objects (Depdiknas, 2003: 18). In accordance with this (Depdiknas, 2003: 2 ), conceptual understanding is one of the skills or mathematical skills that are expected to be achieved in learning mathematics by showing the understanding of mathematical concepts they studied, explain the interconnection between concepts and apply the concept or algorithm in flexible, accurate, efficient, and precise in problem solving.

In the process of learning mathematics, the concept understanding is a very essential part. It is an important foundation for thinking to answer the question in problem solving and daily life. Moreover, understanding the concept is a competence shown by students in knowing the concept and procedure (algorithm) flexibly, accurately, efficiently and appropriately. As for, the indicators of conceptual understanding (Wardhani, 2008: 10) are:

1. Redefine a concept.

2. Classifying objects according to certain traits (in accordance with the concept).

3. Provide examples and nonexamples of concepts.

4. Present the concept in various forms of mathematical representation.

5. Developing necessary or sufficient terms of a concept. 
6. Using, utilizing, and selecting certain procedures or operations.

7. Apply the concept or problem-solving algorithm

The indicator used in designing the concept understanding test consists of four indicators. They are re-stating a concept; developing the necessary or sufficient conditions of a concept; using, utilizing, and selecting a particular procedure or operation; and applying the concept or problem-solving algorithm.

\section{B. Learning Mathematics with Generatif Learning Model (GLM)}

The Generative Learning Model is based on constructivism with the assumption that students are actively building mathematical knowledge. Osborne and Wittrock (1985) stated that:

Generative learning is a learning model that emphasizes on actively integrating new knowledge using the knowledge already possessed by previous knowledge of students. The new knowledge will be stored in answering related issues or symptoms. If the knowledge succeeds in answering the problems encountered, then the new knowledge will be stored in long-term memory.

The Generative Learning Model is based on an inquiry into how humans learn. Through GLM, the knowledge possessed by the student is the result of the activity undertaken by the student and not the passively accepted teaching.
In his theory Wittrock (1974: 182) emphasized that:

The learner is not a passive recipient of information; rather, he or she is an active participant in the learning process, working to construct meaningful understanding of information found the environment.

\section{Softskills in Mathematics Learning}

Mathematics is one of the compulsory subjects that must be taught to all learners ranging from basic education to higher education. Mathematics has a strategic role in human life. None of the humans live normally without the use of Mathematics. This is because there is not a single field of science in practice and development without using Mathematics. Mathematics is quin of science (Mathematics is the science queen).

Mathematics has a strategic role to develop the potential of human thought. In essence, learning mathematics serves to hone the ability of human thinking. Through good mathematics learning, brain learners will be trained and developed so as to have optimal function. In the good process of learning mathematics, student is not just to know and understand the mathematical concepts. Therefore, the process will produce human resources that have:

A. Ability to create mathematical models as a simplification of complex problems

B. Logical reasoning ability

C. Critical and constructive thinking ability 
D. Creative thinking ability that are productive

E. Systemic and systematic analytic thinking skills

F. Good problem solving skills.

\section{DISCUSSION}

According to Osborne and Wittrock (1985) the Generative Learning Model consists of five stages: the orientation stage, the idea-disclosure stage, the challenge and restructuring, the implementation stage, and the looking-back stage.

The first stage is the orientation stage. The orientation stage is motivating students to learn the material taught. Lecturers can link the benefits of new knowledge with daily life or its benefits as a prerequisite for being able to understand other materials. Then, the lecturer guides the students to express existing ideas or knowledge related to new knowledge. The process of connecting new knowledge with existing knowledge will involve motivation. Knowledge of the initial conception will produce meaning and understanding of students in learning. This is supported by the theory of Gagne, that learning must be supported by instructional events, such as motivating students by communicating learning objectives, directing students' attention, generating transfers (generalization), encourage performance and provide feedback.

The second stage is idea disclosure. In this part, students are given the opportunity to express their ideas on learned concepts. Lecturers act as motivators by asking questions that are digging knowledge of students (socratic questioning) so that they will reveal the ideas which exist in the minds of students. The responses and ideas of the students are interpreted and clarified by the lecturers whose purpose is to formulate what strategies should be done in order to learning runs well. When students express an idea, they will realize that there is an opinion that is different from others on the topic being studied. This will create conflicts within itself that cause dissatisfaction with ideas and opinion that will encourage students to make changes. This can be generated by raising of students' awareness of their own ideas; asking them to explain unsuitable concepts, and discussing those concepts. At this stage, students are also given the opportunity to explore their ideas in small group discussions to talk the concepts being studied.

The third stage is challenge and restructuring. In this step, the lecturer increase the cognitive conflict by preparing the conditions in which the student is asked to compare his opinion with his friend's opinion, and strive to reveal the truth/excellence of his opinion. Lecturers then proposed demonstrations to test the veracity of their opinions (Osborne and Wittrock: 1985). It is expected that during this process a conflict arises between what the student have and what the lecturer sees and displays.

After the challenge, students are expected to gain a better understanding of the concept. It is intended to have a desire to strengthen the structure of their understanding of new concepts, students are given challenging questions to arouse their courage in arguing and about the subject being studied.

The fourth stage is the implementation. In this step, students apply their initial concepts plus new concepts that they gain on mathematical problems in the form of question exercises. Students are given the opportunity to solve more complex problems, examine their alternative 
ideas where they build to solve varied problems

Students are expected to consider and evaluate the excellence of new ideas that they develop. This condition provides an opportunity for students to develop their own problem solving strategy. Students will try to solve a problem and do mathematics by actively encouraging them to consider possible strategies for solving a problem. The settlement strategy must be developed by the students with connecting the concepts that have been previously owned and the concepts being studied.

The fifth stage is looking back. Students are given the opportunity to evaluate the weaknesses of their concept. Then, they choose the most effective way/concept in solving the problem. In addition, students are also expected to recall the concept that has been studied as a whole. This condition provides an opportunity for students to reveal about what they have and are working on. What he does is according to what he thinks. Furthermore, the lecturer invites the students to reflect / conclude what they have learned from the learning done by encouraging the students to give answer or response to the question:

A. What I have learned today.

B. What difficulties did I learn today.

C. Which math section do I like.

D. Which part of math I am having trouble with

The steps that have been put forward in the Generative Learning Model are very beneficial for the lecturers to understand the students' way of thinking, and how they get the solution. Thus, students' difficulties in understanding mathematical concepts can be helped or facilitated by lecturers
Hulukati $^{[4]}$ argued that learning activities conducted in the Generative Learning Model show that students are expected to express the concept with the argumentation, to support the concept and expected students to compete with other students. This is expected to have a positive effect because students will be accustomed to appreciate the concept of others and express their opinions without burdened by a sense of wanting to win or fear of losing.

In many ways, teaching is often interpreted as a lecturer's activity: introduces the subject in the beginning, gives one or two examples, then gives one or two questions, and asks the passive student to become more active, by starting from completing the exercise from the book. It is common knowledge that most of the time this activity is carried out in an individual way. Generally, the lesson will end and be well organized. The next lesson usually follows a similar pattern. However, mathematics learning that uses learning where students are actively building their own knowledge can make learning more meaningful and can improve students' understanding of mathematical concepts.

Generative Learning Model based on konstruktivism understanding, which provides an opportunity for students to construct their own knowledge and care about the initial conception (especially students who misconception). The students are expected to be aware of the misconceptions that occur in their mind and willingly correct it. In addition, LGM is based on an inquiry into how humans learn. Thus through Generative Learning Model, the knowledge possessed by the student is the result of the activity undertaken by the student and not the passively accepted teaching. 


\section{CONCLUSION AND SUGGESTION}

The Generative Learning Model (LGM) has five stages: the orientation stage, the disclosure stage of ideas and the focusing stage, the challenge and restructuring phase, the implementation stage and looking back stage. Lecturers can apply LGM as one of the learning model to improve students' math concept concept. Furthermore, lecturers should be able to explore student ideas with questions that are digging (socratic questioning) in order to achieve the goals of the lecture well. This is intended to know better understanding students characteristics and different student abilities in lectures as there are students who are reluctant to work in groups. Moreover, some students are fast and others are slow in getting new concepts of the material being studied.

\section{Bibliography}

[1] Berthal (dalam Muqowim, 2012: 5) dalam artikel "Pengertian dan Arti penting Soft Skills."

[2] Buku Soft

Skills.(2008)."Pengembangan Soft

Skills dalam Proses Belajar di

Perguruan Tinggi". Direktorat

Akademik, Direktorat Jenderal

Pendidikan Tinggi Departemen

Pendidikan Nasional

[3] Didanel."Strategi Pembelajaran Soft Skills dan Multiple Intelegence". tersedia

http://didanel.wordpress.com diakses pada 02 Oktober 2015.

[4] Hulukati, Evi.

2005.

"Mengembangkan Kemampuan

Komunikasi dan Pemecahan Masalah

Matematika Mahasiswa SMP melalui

Model Pembelajaran Generatif”.
Disertasi. Universitas Pendidikan Indonesia.

[5] La Moma. (2013). "Menumbuhkan soft skills siswa dalam pembelajaran Matematika melalui pembelajaran Generatif". Prosiding Seminar Nasional Matematika dan Pendidikan Matematika FTMIPA UNY.ISBN : 978-979-16353-9-4.

[6] Sumaryanto, staf PPTK Matematika."Pengembangan Soft Skills Dalam Pembelajaran Matematika."

[7] Supardi U.S.'Pengembangan Sumber Daya Manusia yang unggul \& kompetitif melalui pembelajaran Matematika untuk menghadapi Masyarakat Ekonomi Asean."

[8] Wikipedia, the free encyclopedia "Soft Skills"

https://en.wikipedia.org/wiki/Soft_skil ls diakses pada 01 Maret 2016.

[9] Wittrock, Merlin C. 1992. Generative Learning Processes of The Brain. Educational Psychologist, 27(4), 531541. University of California, Los Angeles. 